\title{
A Soil Erosion Indicator for Supporting Agricultural, Environmental and Climate Policies in the European Union
}

\author{
Panos Panagos ${ }^{1, *(\mathbb{D})}$, Cristiano Ballabio ${ }^{1}$, Jean Poesen ${ }^{2,3}{ }^{(\mathbb{D}}$, Emanuele Lugato ${ }^{1}{ }^{1}$, \\ Simone Scarpa ${ }^{1}$, Luca Montanarella ${ }^{1}$ and Pasquale Borrelli ${ }^{4,5}$ \\ 1 European Commission, Joint Research Centre (JRC), 21027 Ispra, Italy; cristiano.ballabio@ec.europa.eu (C.B.); \\ emanuele.lugato@ec.europa.eu (E.L.); simone.scarpa@ext.ec.europa.eu (S.S.); \\ luca.montanarella@ec.europa.eu (L.M.) \\ 2 Department Earth and Environmental Sciences, 3001 KU Leuven, Belgium; jean.poesen@kuleuven.be \\ 3 Faculty of Earth Sciences and Spatial Management, Maria-Curie Sklodowska University, \\ 20-718 Lublin, Poland \\ 4 University of Basel, 4056 Basel, Switzerland; pasquale.borrelli@unibas.ch \\ 5 Kangwon National University, Chuncheon-si, Gangwon-do 24341, Korea \\ * Correspondence: panos.panagos@ec.europa.eu; Tel.: +39-0332-785574
}

Received: 14 March 2020; Accepted: 24 April 2020; Published: 26 April 2020

\begin{abstract}
Soil erosion is one of the eight threats in the Soil Thematic Strategy, the main policy instrument dedicated to soil protection in the European Union (EU). During the last decade, soil erosion indicators have been included in monitoring the performance of the Common Agricultural Policy (CAP) and the progress towards the Sustainable Development Goals (SDGs). This study comes five years after the assessment of soil loss by water erosion in the EU [Environmental science \& policy 54, 438-447 (2015)], where a soil erosion modelling baseline for 2010 was developed. Here, we present an update of the EU assessment of soil loss by water erosion for the year 2016. The estimated long-term average erosion rate decreased by $0.4 \%$ between 2010 and 2016. This small decrease of soil loss was due to a limited increase of applied soil conservation practices and land cover change observed at the EU level. The modelling results suggest that, currently, ca. $25 \%$ of the EU land has erosion rates higher than the recommended sustainable threshold $\left(2 \mathrm{tha}^{-1} \mathrm{yr}^{-1}\right)$ and more than $6 \%$ of agricultural lands suffer from severe erosion $\left(11 \mathrm{t} \mathrm{ha}^{-1} \mathrm{yr}^{-1}\right)$. The results suggest that a more incisive set of measures of soil conservation is needed to mitigate soil erosion across the EU. However, targeted measures are recommendable at regional and national level as soil erosion trends are diverse between countries which show heterogeneous application of conservation practices.
\end{abstract}

Keywords: policy support; CAP; SDGs; soil thematic strategy; land degradation; indicators

\section{Background}

The ongoing land degradation processes visible across Europe contribute to raising the question whether policies are effective enough to face current trends [1] and their possible exacerbation due to climate change [2]. The soil governance in the EU has gained increasing importance in recent years, and it is indirectly addressed in different policy areas (agriculture, water, and climate) [3]. In 2006, the European Commission developed a common EU strategy (COM(2006)23) for soil protection including the proposal of a EU Soil Framework Directive. The proposed directive, which would have guided the EU Member States to take actions to prevent soil degradation [4], was withdrawn in 2014 following the lack of agreement between the EU Member States. Today, the Soil Thematic Strategy is the only EU legislation in force that merely concerns soil. With regard to soil erosion, it (a) recognizes soil 
degradation due to erosion as a major threat for food security and the environment; (b) provides a set of overarching principles and calls for stronger integrated policy and; (c) promotes 'raising awareness' and the need for additional research related to soil degradation and protection $[5,6]$.

Before trying to put in place the Soil Thematic Strategy, the EU promoted a more environmentally friendly agriculture by introducing the so-called cross-compliance mechanism in the Common Agricultural Policy (CAP) reform of 2003 [7]. With the introduction of the cross-compliance mechanism, farmer support payments were conditioned on the adoption of environmental, animal welfare and food safety standards. This led to the definition of Good Agricultural and Environmental Conditions (GAEC), first established by the Council Regulation No.1782/2003 and subsequently Council Regulation (EC) No 73/2009. Since 2009, EU Member States have the compulsory requirement to keep their land in good agricultural and environmental conditions under the CAP [8]. The introduction of the GAEC was a further legislative effort to promote prevention and mitigation of soil erosion and maintenance of soil organic matter.

In 2013 (Figure 1), the CAP 2014-2020 reform proposed the sustainable management of natural resources as one of its main objectives [9]. Under the cross-compliance mechanism, Member States were required to define minimum standards for soil protection, such as the minimum soil cover (compulsory) and other management practices such as terraces and grass buffer strips (optional) to limit soil erosion [10]. Under Pillar 1 of the 2014-2020 CAP, the greening practices required the application of crop diversification, maintenance of permanent grasslands (less susceptible to erosion compared to croplands) and ecological focus areas favoring soil conservation. Under Pillar 2 of the 2014-2020 $\mathrm{CAP}$, the prevention of soil erosion (through practices of conservation agriculture, and green covers) was one of the priorities of rural development. The 2014-2020 CAP also put in place a monitoring and evaluation framework to assess the environmental impact of farming through indicators of soil protection, namely: (a) soil erosion by water and; (b) soil organic matter.

\begin{tabular}{|c|c|c|c|c|}
\hline $\begin{array}{c}\text { Agricultural \& } \\
\text { Environmental } \\
\text { Conditions (GAEC) }\end{array}$ & $\begin{array}{c}\text { Soil Thematic } \\
\text { Strategy }\end{array}$ & $\begin{array}{c}\text { CAP } \\
2014-2020\end{array}$ & $\begin{array}{c}\text { Sustainable } \\
\text { Development } \\
\text { Goals }\end{array}$ & $\begin{array}{c}\text { CAP } \\
2021-2027\end{array}$ \\
\hline 2003 & 2006 & inte. & 15 off Land & $\begin{array}{l}\text { CAP post 2020.1. } \\
\text { Impact Assessment }\end{array}$ \\
\hline
\end{tabular}

Figure 1. Policy development in the EU in relation to soil erosion reduction.

At the global scale, the United Nations agreed, in 2015, on the adoption of the Sustainable Development Goals (SDGs) as a major policy driver towards sustainable development and well-being [11]. The EU has been a front-runner in monitoring the SDGs by developing a set of indicators at the EU level [12], taking into account recent policy developments and improved data availability. This comprises 100 indicators relevant for monitoring progress towards the SDGs, including soil erosion by water which refers to both SDG2 (zero hunger) and SDG15 (life on land) [13].

The post 2020 CAP reform (2021-2027), currently under discussion in the European Parliament, includes nine objectives and three of them aim to implement environmental and climate change actions: (a) Contribute to climate change mitigation/adaptation; (b) foster sustainable development and efficient management of water soil and air, and; (c) contribute to biodiversity protection and ecosystem services (European Commission, 2018) [14,15]. The proposed 2021-2027 CAP regulation sets soil erosion among 
the 28 indicators to monitor the impact and performance of this policy [15]. Among others, the Member States will establish management plans to reduce the percentage of agricultural land under severe erosion (> $11 \mathrm{t} \mathrm{ha}^{-1} \mathrm{yr}^{-1}$ ). In the post $2020 \mathrm{CAP}$, the proposed GAEC include, among others, a ban on burning arable stubble, protection of bare soils in winter with cover crops, and crop rotation and tillage management in areas of soil degradation (sloping arable lands).

Briefly, the current policy framework (Figure 1) for soil protection is fragmented and cannot entirely implement measures against soil threats and towards improving soil functions [16,17]. However, monitoring indicators can measure and evaluate the soil governance instruments [18]. The development of effective indicators, related to land processes occurring at continental scale, requires a state-of-the-art methodology, able to detect changes under environmental pressures and policy drivers [13].

In the past, different modelling approaches have been developed at the continental scale, such as the PESERA [19] and the erosion rates based on runoff plot data [20]. Even though these studies are advancing the knowledge on soil erosion processes and modelling, they do not offer the possibility to assess the impact of conservation practices on mitigating soil erosion and the role of agri-environmental policies. For these reasons, the application of the RUSLE2015 model [21], previously developed and tailored to the European context, was applied to estimate the erosion rates in 2016.

The main objective of this paper is to present the soil erosion indicator development as a response to the EU agri-environmental policy requests. Here, we present an update of the assessment of soil loss by water erosion for the year 2016 and the changes from 2010.

\section{Materials and Methods}

\subsection{Modelling Soil Erosion at Continental Scale}

The revised universal loss equation (RUSLE) [22] estimates the mean annual soil loss rates by sheet and rill erosion. The RUSLE model is based on the following equation:

$$
\mathrm{E}=\mathrm{R} \times \mathrm{K} \times \mathrm{C} \times \mathrm{LS} \times \mathrm{P}
$$

where $\mathrm{E}\left(\mathrm{t} \mathrm{ha} \mathrm{yr}^{-1} \mathrm{yr}^{-1}\right)$ is the annual average soil loss, $\mathrm{R}\left(\mathrm{MJ} \mathrm{mm} \mathrm{ha} \mathrm{m}^{-1} \mathrm{~h}^{-1} \mathrm{yr}^{-1}\right)$ is the rainfall-runoff erosivity factor, $\mathrm{K}$ ( $\mathrm{t}$ ha $\mathrm{h} \mathrm{ha} \mathrm{h}^{-1} \mathrm{MJ}^{-1} \mathrm{~mm}^{-1}$ ) is the soil erodibility factor, LS (dimensionless) is the slope length and slope steepness factor, $\mathrm{C}$ (dimensionless) is the cover-management factor and $\mathrm{P}$ (dimensionless) is the support practices factor.

Despite the limitations in the model structure [23], RUSLE is the most frequently used tool for water erosion estimation [24]. In addition, the model is the most appropriate for developing indicators and trends of soil erosion by water [25,26]. A European version of RUSLE, named RUSLE2015 [21], has been adjusted to the continental scale in order to estimate the input factors based on the best available and harmonized input data layers (Figure 2).

\subsection{Static Factors}

The soil organic carbon changes in such a short period (6-years) are not significant. Soil properties, used in the RUSLE2015, do not change in 6 years-time and the topography is not significantly altered. Therefore, for the estimation of soil loss rates in 2016, the erodibility factor [27] and the slope length and steepness factor [28] are set equal to those for the 2010 indicator. The rainfall erosivity is a long-term average of annual erosivity records which has been calculated based on high temporal rainfall records for a mean of 17-years covering the first decade of 2000. As it is difficult to quantify the effect of climate change in terms of erosivity in such a short period (2010-2016), we have used the pan-European R-factor for 2016 [29]. 


\subsection{Dynamic Factors and Land Cover Changes}

The dynamic parts of the RUSLE2015 model are the cover-management (C-factor) and the support practices (P-factor) (Figure 2). In more detail, the $\mathrm{C}$-factor incorporates the changes in land cover and the management practices applied in arable lands (tillage, cover crops, and plant residues). In addition, the P-factor considers the changes in grass margins and stone walls. Briefly, the cover-management (C-factor) and the support practices (P-factor) quantify the human interventions and the impact of agri-environmental policies in the short-term (Figure 2).

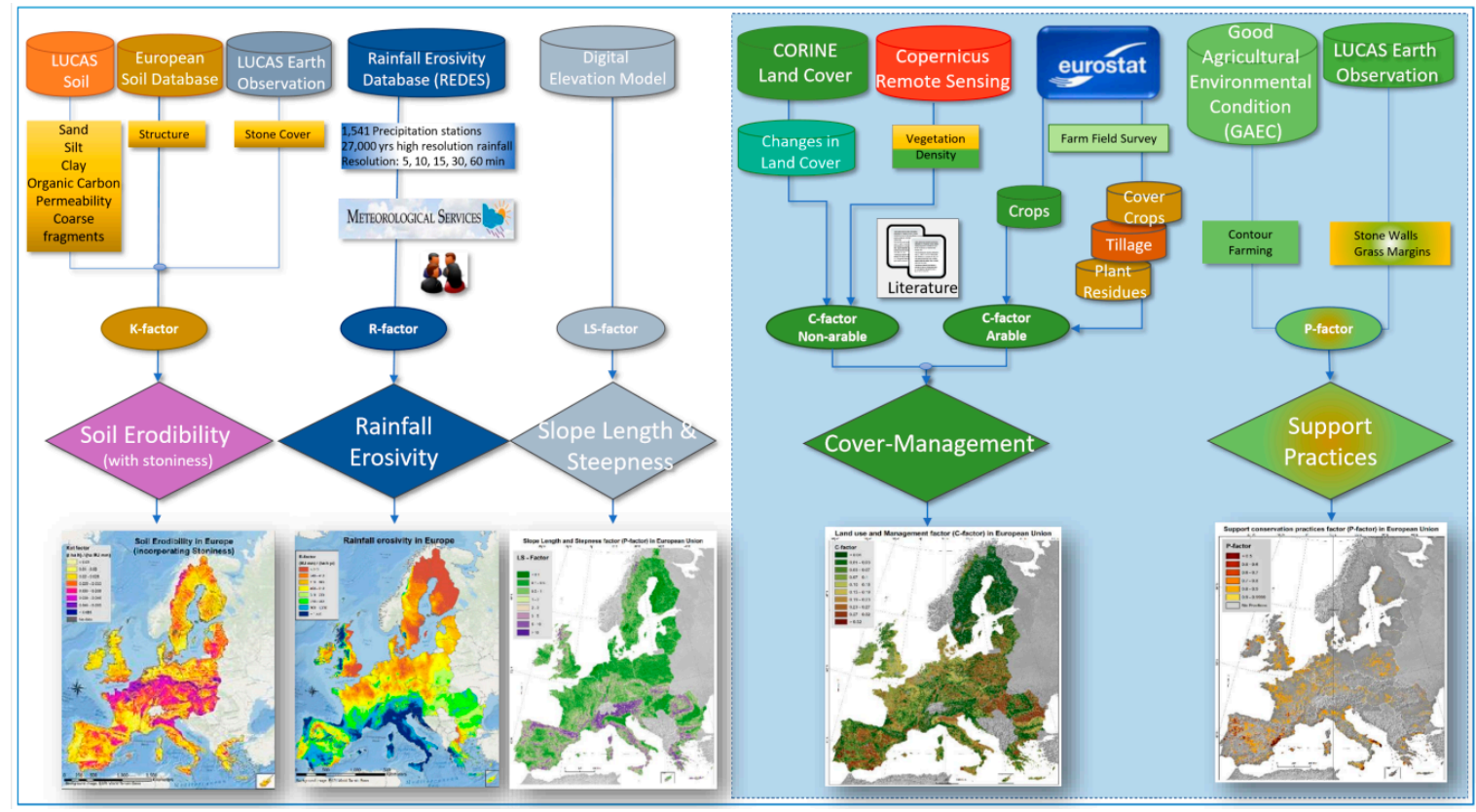

Figure 2. Description of RUSLE2015 model adapted to produce the soil erosion indicator for 2016 (shaded right part is the dynamic component).

The CORINE land cover (CLC) is an inventory initiated in 1990 and updated in 2000, 2006 and 2012 [30], while 2018 data are still under validation. The 2010 soil erosion assessment used the 2006 CLC dataset. In the updated 2016 soil erosion assessment, we developed a hybrid land cover layer using the 2006 CLC dataset and applying the land cover changes for the period 2006-2012 (CLC 2006-2012) [31]. As the objective of the indicators is to track the changes in time, the best available layer representing the land cover change between the 2 periods is the CLC 2006-2012. In addition, the Copernicus website advises users interested in CLC-changes to always rely on the corresponding CLC-changes product and never on the difference (intersect) of the two status layers.

\subsection{Changes in Tillage Practices, Cover Crops and Plant Residues}

The statistical office of the European Union (EUROSTAT) performed the Farm Structure Survey (FSS) twice (2010 and 2016), collecting data from EU Member States (MS) on agri-environmental measures. Countries collect the information from individual agricultural holdings and transmit them, aggregated at the regional level, to EUROSTAT. In the RUSLE2015 model, we also used data on reduced soil tillage, cover crops and plant residues (Figure 2) to estimate the C-factor in arable lands [32].

The total arable land in the EU is about 1.09 million $\mathrm{Km}^{2}$. In 2016, conservation tillage was applied in $22.4 \%$ of EU arable lands ( $+0.8 \%$ compared to 2010$)$ and no-till farming has a share of $4.2 \%(+0.2 \%)$. For the period 2010-2016, conservation tillage increased in France, Austria, Estonia and Portugal (overall country increase $>7 \%$ ), while decreases were recorded in Bulgaria, Greece, Poland (overall country decreases $<-4 \%$ ) and parts of Italy. Cover crops have increased quite substantially in 6-years (2010-2016) as they were applied in 8.9\% of EU arable lands, compared to $6.5 \%$ in 2010 [31]. On the 
contrary, the soil cover by plant residue management shows a decrease of $1.5 \%$ compared to 2010 and has been applied in 9.1\% of EU arable lands. For the period 2010-2016, we have also mapped the sub-national (NUTS2) changes (\%) of the average C-factor in arable lands due to soil tillage practices, cover crops and plant residues [31].

\subsection{Changes in Grass Margins and Support Practices Factor $(P)$}

In a similar way, as in 2010, the P-factor in the RUSLE2015 model is estimated as the product of 3 sub-factors [33]:

$$
\mathrm{P}=\mathrm{Pc} \times \mathrm{Psw} \times \mathrm{Pgm}
$$

where Pc is the contouring sub-factor for a given slope of a field, and Psw is the stone walls sedimentation sub-factor (known as terrace sub-factor), and Pgm is the grass margins sub-factor (known as strip cropping sub-factor and includes effects of grass buffer strips). The use of these 3 sub-factors in RUSLE has been discussed elsewhere [34,35].

The main data source for grass margins and stone walls is the Land Use and Coverage Area Frame Survey (LUCAS) [36], which was performed in the EU in 2015 [37]. For each of the 270,000 LUCAS points, the surveyor walked eastwards along a transect of $250 \mathrm{~m}$ and recorded landscape features; among them the grass margins and the stone walls were relevant as support practices reducing soil erosion by water.

The efficiency of grass margins in controlling soil erosion by water is highly variable and depends on many factors (i.e., slope, soil type, buffer strip type, width, age, magnitude of erosive events, etc.) [38]. Grass margins have a larger erosion-reducing effect compared to their effect on runoff [39]. Compared to conservation agriculture and reduced tillage, the grass margins show smaller soil erosion mitigation effects, but can still contribute in reducing runoff, especially in low-intensity erosive events [40].

Compared to the previous LUCAS survey (2012), the total number of grass margins in the study area (EU and UK) increased from 61,224 to 66,378 (+8.4\%) in 2015 (Table 1). For the total number, we summed up the number of LUCAS survey observations with presence of grass margins. For density, we estimated the percentage of observations with grass margins compared to the total number of observations (Table 1). With the exception of BENELUX (Belgium, Luxembourg, and Netherlands) and Bulgaria, all the other countries showed an increase of total number of grass margins. The largest increases in the period 2012-2015 were found in Ireland (+53\%), Latvia (+25\%), Slovenia (24\%) and Finland (22\%) (Table 1). The increase of the grass margins trend (mainly attributed to greening of the CAP 2014-2020) is expected to be confirmed with data at the end of 2020. In the whole study area, the density of grass margins was less than $30 \%$. The highest density of grass margins was found in Belgium (44\%), Luxembourg, France, Denmark and United Kingdom (>35\%). Croatia, Sweden and Latvia had the lowest density of grass margins $(<15 \%)$.

Taking the grass margins dataset produced with the 2012 LUCAS survey [33] with the ordinary kriging methodology [41] as a baseline, we then applied the differences between the 2012 and 2015 datasets. The grass margins sub-factor (in Equation (2)) takes either the value 1 (in case of 0 grass margins) or values in the range $0.66-0.85$, depending on the density of grass margins in the transect [33].

The rest of the sub-factors (Pc, Psw) did not change in the current model application. The contour sub-factor $(\mathrm{Pc})$ is mainly driven by changes in GAEC conditions for contour farming in sloping areas, and major changes did not occur for that period. Regarding stone walls, their density (amount of observations with stone walls divided by the total number of observations) is less than 5\%. In addition, stone walls do not frequently increase over time because important capital investments are requested. Based on LUCAS 2015 observations, we noticed an increase of 1084 stone walls compared to 2012, but almost half of them were recorded in Sweden. We decided not to take into account this change in order to avoid introducing possible 'noise' into our model results. The effect of stone walls change in the period 2012-2015 is insignificant, also due to the occasional density $(<5 \%)$ of this feature. 
Table 1. Comparison of grass margins in the EU according to the LUCAS survey in 2012 and 2015.

\begin{tabular}{|c|c|c|c|c|c|c|}
\hline \multicolumn{2}{|l|}{ Country } & \multicolumn{3}{|c|}{$\begin{array}{c}\text { Number of Observations with Presence } \\
\text { of Grass Margins }\end{array}$} & \multirow{2}{*}{$\begin{array}{c}\text { Total No. of } \\
\text { Observations } \\
\quad(2015)\end{array}$} & \multirow{2}{*}{$\begin{array}{l}\text { Density }(\% \\
\text { in } 2015\end{array}$} \\
\hline Name & Code & 2012 & 2015 & $\begin{array}{l}\text { \% Difference } \\
\text { 2012-2015 }\end{array}$ & & \\
\hline Austria & $\mathrm{AT}$ & 1593 & 1634 & $2.6 \%$ & 5241 & $31.2 \%$ \\
\hline Belgium & $\mathrm{BE}$ & 1014 & 942 & $-7.1 \%$ & 2133 & $44.2 \%$ \\
\hline Bulgaria & BG & 1319 & 1287 & $-2.4 \%$ & 5153 & $25.0 \%$ \\
\hline Cyprus & $\mathrm{CY}$ & 164 & 193 & $17.7 \%$ & 1224 & $15.8 \%$ \\
\hline Czechia & $\mathrm{CZ}$ & 784 & 843 & $7.5 \%$ & 5358 & $15.7 \%$ \\
\hline Germany & $\mathrm{DE}$ & 7416 & 7768 & $4.7 \%$ & 23,177 & $33.5 \%$ \\
\hline Denmark & DK & 995 & 1204 & $21.0 \%$ & 3262 & $36.9 \%$ \\
\hline Estonia & $\mathrm{EE}$ & 273 & 272 & $-0.4 \%$ & 1583 & $17.2 \%$ \\
\hline Greece & GR & 1379 & 1504 & $9.1 \%$ & 6223 & $24.2 \%$ \\
\hline Spain & ES & 9020 & 9663 & $7.1 \%$ & 29,990 & $32.2 \%$ \\
\hline Finland & FI & 2080 & 2542 & $22.2 \%$ & 11,517 & $22.1 \%$ \\
\hline France & FR & 12,161 & 13,130 & $8.0 \%$ & 33,713 & $38.9 \%$ \\
\hline Croatia & HR & & 319 & & 2487 & $12.8 \%$ \\
\hline Hungary & $\mathrm{HU}$ & 1084 & 1156 & $6.6 \%$ & 4225 & $27.4 \%$ \\
\hline Ireland & IE & 419 & 642 & $53.2 \%$ & 2524 & $25.4 \%$ \\
\hline Italy & IT & 5256 & 5475 & $4.2 \%$ & 15,723 & $34.8 \%$ \\
\hline Lithuania & LT & 619 & 648 & $4.7 \%$ & 3457 & $18.7 \%$ \\
\hline Luxembourg & $\mathrm{LU}$ & 77 & 74 & $-3.9 \%$ & 188 & $39.4 \%$ \\
\hline Latvia & $\mathrm{LV}$ & 403 & 507 & $25.8 \%$ & 3475 & $14.6 \%$ \\
\hline Malta & MT & 20 & 21 & $5.0 \%$ & 69 & $30.4 \%$ \\
\hline Netherlands & $\mathrm{NL}$ & 714 & 659 & $-7.7 \%$ & 1958 & $33.7 \%$ \\
\hline Poland & PL & 5599 & 6160 & $10.0 \%$ & 19,231 & $32.0 \%$ \\
\hline Portugal & $\mathrm{PT}$ & 1131 & 1257 & $11.1 \%$ & 5758 & $21.8 \%$ \\
\hline Romania & $\mathrm{RO}$ & 1948 & 2071 & $6.3 \%$ & 9759 & $21.2 \%$ \\
\hline Sweden & SE & 1891 & 2137 & $13.0 \%$ & 16,133 & $13.2 \%$ \\
\hline Slovenia & SI & 300 & 372 & $24.0 \%$ & 1402 & $26.5 \%$ \\
\hline Slovakia & SK & 295 & 350 & $18.6 \%$ & 2067 & $16.9 \%$ \\
\hline United Kingdom & UK & 3270 & 3548 & $8.5 \%$ & 9114 & $38.9 \%$ \\
\hline Total & & 61,224 & 66,378 & $8.4 \%$ & 226,144 & $29.4 \%$ \\
\hline
\end{tabular}

\subsection{Building a Framework for Indicators for Monitoring Soil Erosion}

During the last decades, the evaluation of agricultural performances has moved from the single criterion of productivity towards broader measures, such as environmental performances [42]. In 1999, the Organisation for Economic Co-operation and Development (OECD) proposed the agri-environmental indicators (AEIs) framework for environmental monitoring, with the aim to provide information about the state of the environment [43]. In the EU, the development of AEIs started with the reinforcement of sustainability policies (e.g., Water Framework Directive, GAEC, Soil Thematic Strategy, etc.) in the early 2000s.

In this context, EU policy makers need to know which areas are vulnerable to soil erosion and compare these to other regions in the EU. As the actual rates of soil erosion are impossible record due to the very high monitoring and data-analysis costs, the erosion estimates are based on bio-physical models necessary to support policy. 
To monitor the impact of the CAP in reducing soil erosion rates, policy makers proposed the indicator "percentage of agricultural area affected by severe erosion (\%)". As severe erosion, OECD propose the threshold of $11 \mathrm{t} \mathrm{ha}^{-1} \mathrm{yr}^{-1}$ [44]. This indicator is included in a package of 28 agri-environmental indicators which contribute to the monitoring and evaluation framework of the CAP 2014-2020. These indicators are used in rural development programmes for a comprehensive description of the situation of each programming area (country or regional level).

As the EU is also a front-runner in monitoring the SDGs, and more specific the SDG15 (life on land), a second indicator was proposed to assess sustainability, namely: "estimated mean soil erosion rate in $\mathrm{t} \mathrm{ha}^{-1} \mathrm{yr}^{-1 "}$ aggregated at different spatial levels (i.e., country, region, and province). In this study, we used the nomenclature of territorial units for statistics (NUTS) which is an official classification used by the statistical services of the EU. This system divides the economic territory of the EU into different levels for the purpose of regional statistics. At the second level (NUTS2), the units represent basic regions for the application of regional policies [45]. The indicators are updated every 5-6 years when new updated datasets on land cover/land use and management practices become available.

In addition to the CAP environmental monitoring, the soil erosion indicator dataset can also estimate the impact of soil erosion on water pollution or even on societal costs. For example, the estimation of transported sediments by water erosion per river basin and catchment [46] can be useful to monitor the Water Framework Directive. Another example is the impact of soil erosion on agricultural productivity loss and decline in crop yields which has been quantified recently in monetary terms [47].

\section{Results}

\subsection{C-Factor Update}

In the period 2010-2016 the mean European C-factor of the RUSLE in arable lands has decreased by $-0.84 \%$ from 0.2336 to 0.2316 [31]. The land cover change between the two CORINE versions $(2006,2012)$ is about 750,000 ha with $26 \%$ of this area being converted from arable lands to pastures. The increase of land under soil conservation practices and the land cover change have contributed to decreasing the mean C-factor by $-0.7 \%$ (from 0.1043 in 2010 to 0.1036 in 2016).

\subsection{P-Factor Update}

The mean grass margins sub-factor (Pgm) is reduced from 0.9829 in 2012 to 0.9804 in 2015 which is a very small decrease of ca. $-0.3 \%$. In a similar way, the mean P-factor in the study area (EU and UK) was reduced in the same period from 0.9702 to 0.9681 which is a very small decrease of $-0.2 \%$. The impact of grass margins change in reducing soil erosion is limited, as this measure did not substantially change in the 2010-2016 period. It is evident that a stronger package of soil conservation practices (e.g., cover crops, plant residues, reduced tillage, contouring, stone walls, grass margins) is needed to further reduce soil erosion in hotspots.

\subsection{Soil Erosion Rates and Derived Indicators in 2016}

The potentially erosion-susceptible area in the study is ca. $3912 \times 10^{3} \mathrm{Km}^{2}$, corresponding to $89.6 \%$ of the total area (Figure 3a). Since 2010, the areas not susceptible to water erosion such as cities, urban areas, bare rocks, glaciers, wetlands, lakes, rivers and marine waters have increased mainly due to urbanization and a decrease of shrublands. The spatial scale of the soil loss by water erosion map for 2016 is at $100 \mathrm{~m}$ resolution as a compromise between low resolution input factors $(\mathrm{K}, \mathrm{R}, \mathrm{P})$ and higher resolution ones (LS, C). In addition, the $100 \mathrm{~m}$ resolution is the spatial scale of C-factor which is the most influential for erosion rates changes and the most sensitive one. 


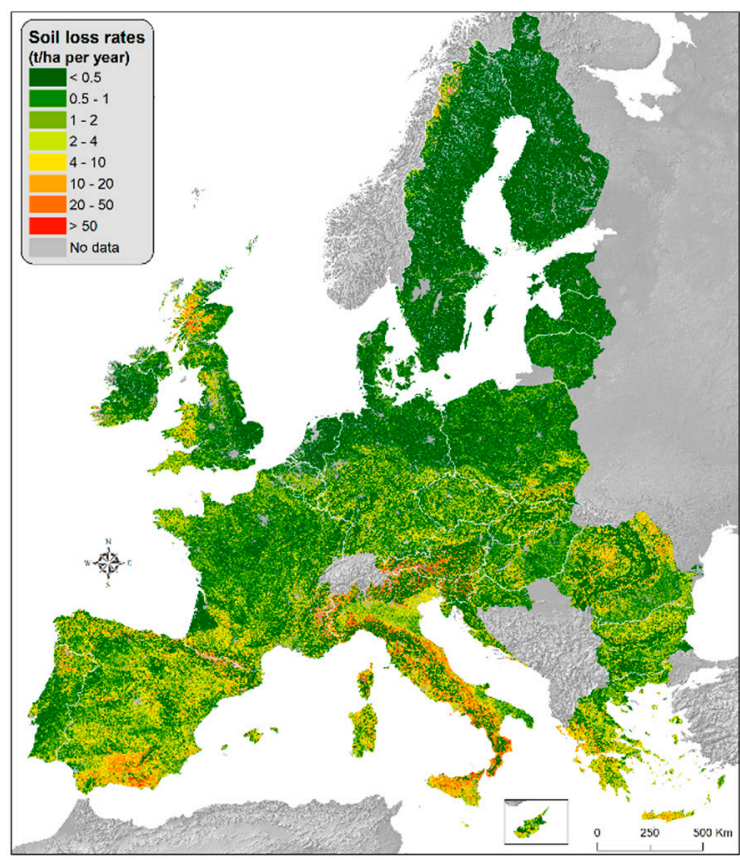

(a)

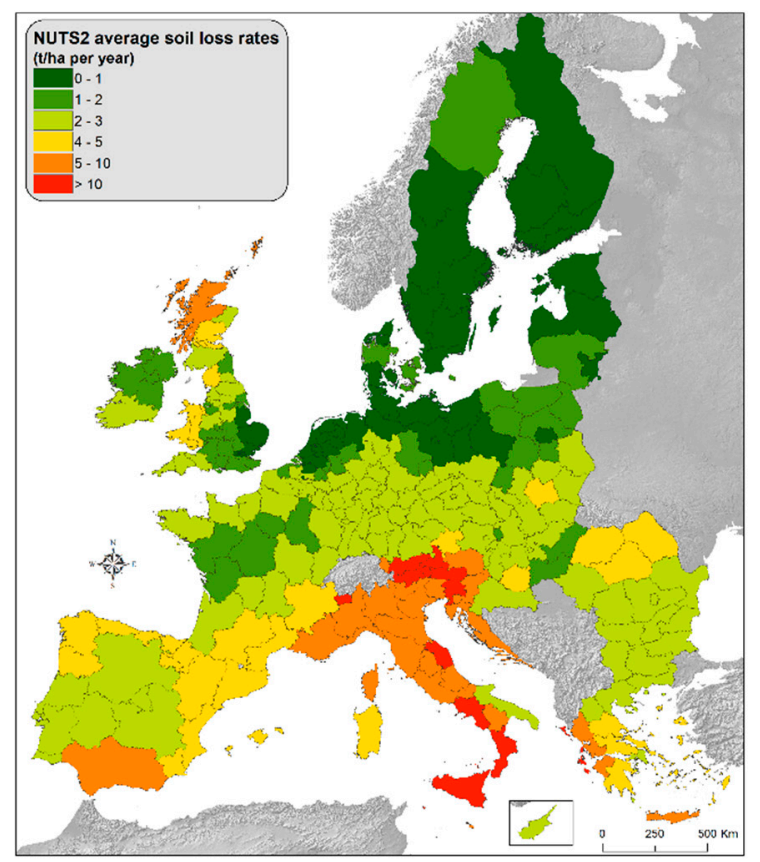

(b)

Figure 3. (a) The updated soil loss rates by water erosion (2016); (b) The indicator "estimated mean soil erosion rate $\left(\mathrm{t} \mathrm{ha}^{-1} \mathrm{yr}^{-1}\right)^{\prime \prime}$.

The mean soil erosion rate in 2016 is estimated to be $2.45 \mathrm{t} \mathrm{ha}^{-1} \mathrm{yr}^{-1}$, which is close to the 2010 value $\left(2.46 \mathrm{t} \mathrm{ha}^{-1} \mathrm{yr}^{-1}\right)$. This decline of $0.4 \%$ in 6 years is much smaller than the reduction estimated for the period 2000-2010 (-9\%). This means that the efforts to mitigate soil erosion need to be reinforced with more agri-environmental friendly measures and better target areas with high erosion risk.

The geographical distribution of the mean erosion rates suggests an increase in 8 countries and a decrease in 20 countries (Table 2). Among the latter ones, there are apparent positive signs of increasing applications of soil conservation practices in Austria, Denmark, Germany, Estonia, France Malta and Portugal. In those countries, the application of conservation practices reduced erosion rates by at least $3.5 \%$ in arable lands. According to the statistics driving the model, compared to 2010, Bulgaria shows a lower implementation of management practices to reduce soil erosion in 2016, which led to a mean soil erosion rate of $2.18 \mathrm{t} \mathrm{ha}^{-1} \mathrm{yr}^{-1}$ (+5.9\% compared to 2010). The three Mediterranean countries with the highest erosion rates, i.e., Italy $\left(8.59 \mathrm{t} \mathrm{ha}^{-1} \mathrm{yr}^{-1}\right)$, Spain $\left(4.0 \mathrm{t} \mathrm{ha}^{-1} \mathrm{yr}^{-1}\right)$ and Greece $\left(4.19 \mathrm{t} \mathrm{ha}^{-1} \mathrm{yr}^{-1}\right)$ show an increase of mean rates by at least $1.5 \%$ compared to 2010 . If those 3 countries had maintained the same level of management practices as in 2010 , then the mean soil erosion rate in study area would have been reduced in 2016 to $2.43 \mathrm{tha}^{-1} \mathrm{yr}^{-1}(-1.3 \%)$.

The high resolution of spatial soil erosion patterns (Figure 3a) in 2016 are similar to those of 2010 [21]. By aggregating the data at regional level, the indicator "estimated mean soil erosion rate as $t$ $\mathrm{ha}^{-1} \mathrm{yr}^{-1 \text { " }}$ is calculated (Figure 3b). The estimated total annual erosion in 2016 is ca. 960 million tons, which slightly decreased by ca. 10 million tons, compared to 2010 [21]. The major part of this soil loss is deposited close to the eroded area and remains on the hillslopes as ca. only $15 \%$ of the total soil loss reaches the rivers or other water bodies [46]. 
Table 2. Comparison of soil loss rates for 2010 and 2016 (all lands, arable lands).

\begin{tabular}{|c|c|c|c|c|c|c|c|}
\hline \multirow[t]{2}{*}{ Country } & & \multicolumn{3}{|c|}{$\begin{array}{l}\text { Mean Soil Loss Rates }\left(t h a^{-1} y r^{-1}\right) \\
\text { for All Lands }\end{array}$} & \multicolumn{3}{|c|}{$\begin{array}{c}\text { Mean Soil Loss Rates }\left(t h a^{-1} y r^{-1}\right) \\
\text { in Arable Lands (CORINE } \\
\text { Classes 21x) }\end{array}$} \\
\hline & & 2010 & 2016 & Change (\%) & 2010 & 2016 & Change (\%) \\
\hline Austria & AT & 7.19 & 7.19 & $-0.1 \%$ & 3.97 & 3.79 & $-4.5 \%$ \\
\hline Belgium & BE & 1.22 & 1.22 & $0.1 \%$ & 2.06 & 2.04 & $-0.8 \%$ \\
\hline Bulgaria & BG & 2.05 & 2.18 & $5.9 \%$ & 2.47 & 2.79 & $12.6 \%$ \\
\hline Cyprus & CY & 2.89 & 2.99 & $3.3 \%$ & 1.85 & 1.84 & $-0.6 \%$ \\
\hline Czechia & $\mathrm{CZ}$ & 1.65 & 1.63 & $-0.7 \%$ & 2.52 & 2.52 & $0.0 \%$ \\
\hline Germany & $\mathrm{DE}$ & 1.25 & 1.23 & $-1.9 \%$ & 1.75 & 1.69 & $-3.5 \%$ \\
\hline Denmark & DK & 0.50 & 0.47 & $-5.7 \%$ & 0.61 & 0.57 & $-6.8 \%$ \\
\hline Estonia & $\mathrm{EE}$ & 0.21 & 0.19 & $-6.8 \%$ & 0.70 & 0.62 & $-11.0 \%$ \\
\hline Greece & EL & 4.13 & 4.19 & $1.6 \%$ & 2.77 & 2.90 & $4.8 \%$ \\
\hline Spain & ES & 3.94 & 4.00 & $1.5 \%$ & 4.27 & 4.34 & $1.7 \%$ \\
\hline Finland & FI & 0.06 & 0.06 & $-0.4 \%$ & 0.46 & 0.46 & $-1.1 \%$ \\
\hline France & FR & 2.25 & 2.20 & $-2.4 \%$ & 1.99 & 1.83 & $-8.2 \%$ \\
\hline Croatia & HR & 3.16 & 2.41 & $-23.7 \%$ & 1.67 & 1.70 & $1.4 \%$ \\
\hline Hungary & HU & 1.62 & 1.61 & $-0.8 \%$ & 2.10 & 2.09 & $-0.4 \%$ \\
\hline Ireland & IE & 0.96 & 0.95 & $-1.1 \%$ & 1.32 & 1.34 & $2.0 \%$ \\
\hline Italy & IT & 8.46 & 8.59 & $1.5 \%$ & 8.38 & 8.62 & $2.8 \%$ \\
\hline Lithuania & LT & 0.52 & 0.51 & $-0.5 \%$ & 0.95 & 0.94 & $-0.6 \%$ \\
\hline Luxembourg & LU & 2.07 & 2.07 & $-0.2 \%$ & 4.54 & 4.41 & $-3.0 \%$ \\
\hline Latvia & LV & 0.32 & 0.33 & $2.2 \%$ & 1.01 & 1.03 & $1.6 \%$ \\
\hline Malta & MT & 6.02 & 4.47 & $-25.7 \%$ & 15.93 & 9.49 & $-40.5 \%$ \\
\hline Netherlands & NL & 0.27 & 0.26 & $-2.5 \%$ & 0.54 & 0.52 & $-3.7 \%$ \\
\hline Poland & PL & 0.96 & 0.99 & $2.3 \%$ & 1.61 & 1.66 & $3.3 \%$ \\
\hline Portugal & PT & 2.31 & 2.17 & $-6.0 \%$ & 2.94 & 2.75 & $-6.5 \%$ \\
\hline Romania & RO & 2.84 & 2.80 & $-1.6 \%$ & 3.39 & 3.27 & $-3.6 \%$ \\
\hline Sweden & SE & 0.41 & 0.40 & $-1.6 \%$ & 1.12 & 1.11 & $-1.0 \%$ \\
\hline Slovenia & SI & 7.43 & 7.46 & $0.3 \%$ & 4.63 & 4.60 & $-0.7 \%$ \\
\hline Slovakia & SK & 2.18 & 2.16 & $-0.9 \%$ & 3.54 & 3.47 & $-2.2 \%$ \\
\hline United Kingdom & UK & 2.38 & 2.37 & $-0.2 \%$ & 1.04 & 1.00 & $-4.2 \%$ \\
\hline European Union & EU & 2.46 & 2.45 & $-0.4 \%$ & 2.67 & 2.65 & $-0.8 \%$ \\
\hline
\end{tabular}

As the agri-environmental policies are implemented at regional level, we have aggregated the soil erosion rates per region (Figure 4). For the indicator "percentage (\%) of agricultural area affected by severe erosion $\left(>11 \mathrm{t} \mathrm{ha}^{-1} \mathrm{yr}^{-1}\right)^{\prime \prime}$, we estimate that ca. $6.6 \%$ of the total agricultural area in the EU suffered from severe erosion in 2016. In those 14.2 million ha of agriculture area suffering from severe erosion (including permanent crops, grasslands and pastures), further policy interventions are required to halt severe erosion. 


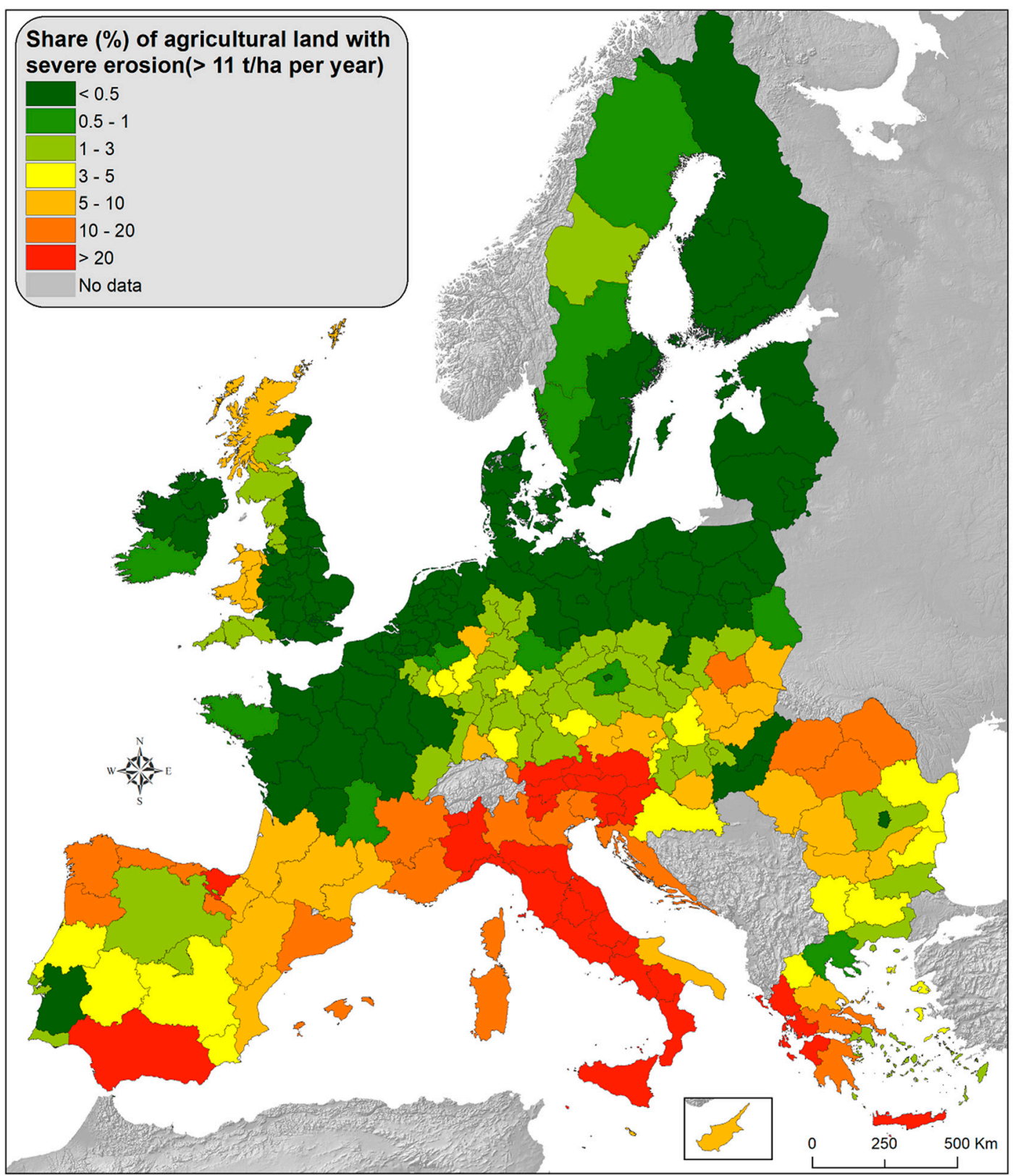

Figure 4. Indicator "percentage of agricultural area affected by severe erosion $\left(>11 \mathrm{tha}^{-1} \mathrm{yr}^{-1}\right)^{\text {". }}$

Arable land and permanent crops were estimated to be more affected by erosion as $7.2 \%$ of those areas show severe erosion rates compared to the $4.4 \%$ found in permanent grasslands and pastures. The countries with the highest percentage of cultivated area under severe erosion are Slovenia (41.1\%), Italy (33.3\%), Greece (11.6\%), Austria (10.8\%) and Spain (10.1\%).

In the Sustainable Development Goals (SDG) framework, the indicator "estimated mean soil erosion rate as $\mathrm{tha}^{-1} \mathrm{yr}^{-1 "}$ takes into account all land cover types (Table 2). Arable lands show a small decrease of erosion rates (2.65 $\mathrm{t} \mathrm{ha}^{-1} \mathrm{yr}^{-1}$ in 2016 compared to 2.67 in 2010), while all the remaining lands have similar mean values as in 2010 (Table 2). The key driver for change in soil erosion is the application of soil conservation practices (i.e., reduced tillage, plant residues, grass margins and cover crops) which are mainly targeting arable lands. For the cases in which soil erosion rates decrease between 2010 and 2016, the reduction is larger in arable lands than in all lands. If the change in erosion rate in arable lands is smaller than that for all lands, then the land cover change is more important than the variation of applied soil conservation practices. According to Table 2, few countries (e.g., 
Ireland and, to a lesser degree, Sweden) show a land cover change (increase of more erosive-prone areas) which is more dominant compared to a change in applied soil conservation practices.

\section{Discussion}

\subsection{Progress in the Soil Erosion Indicators}

The progress of the soil erosion indicators is more obvious at regional level. Even if the spatial patterns of the soil erosion datasets $(2010,2016)$ are similar, the differences in mean soil erosion rates are evident when we aggregate the differences at regional level (Figure 5).

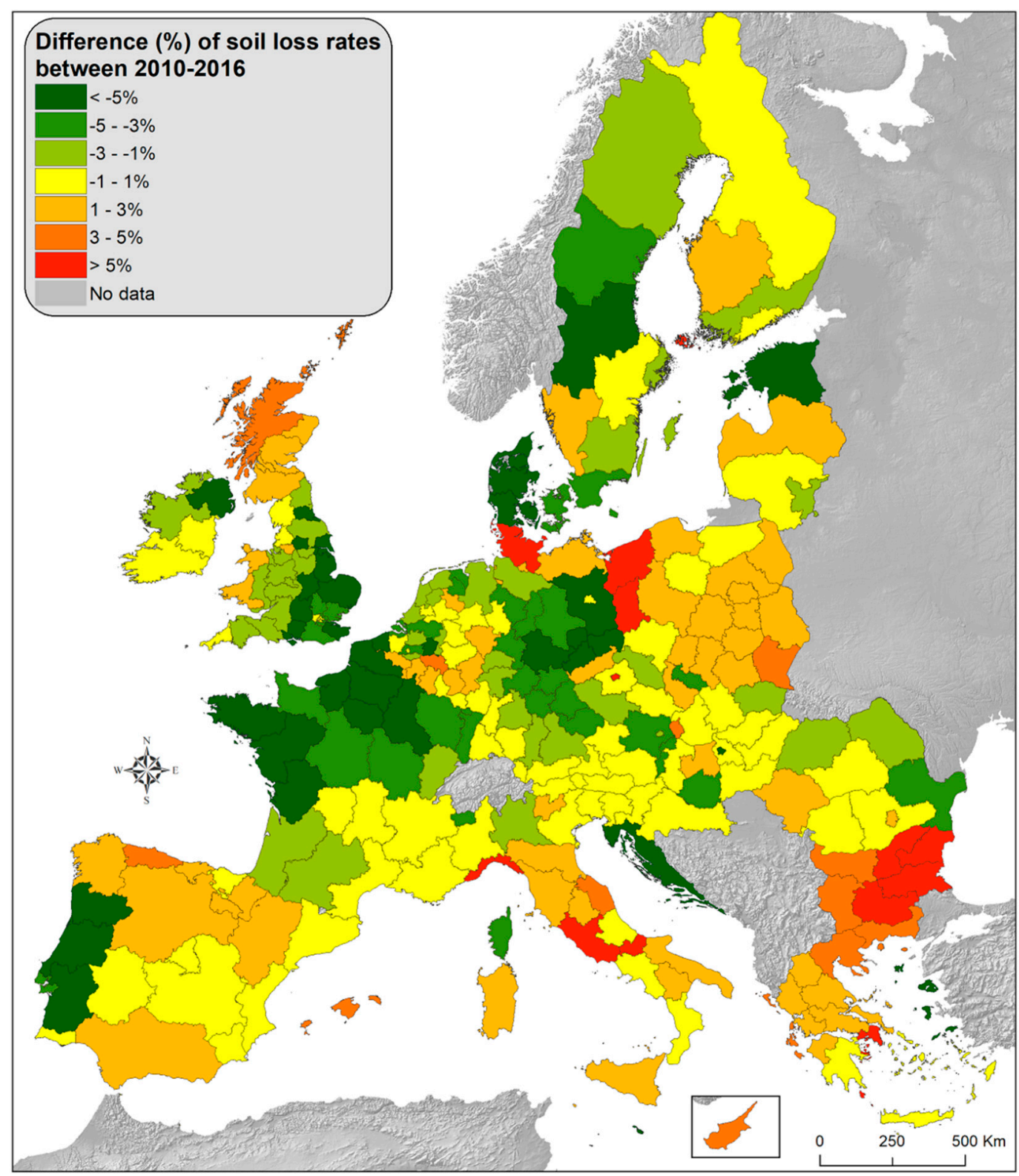

Figure 5. Progress of soil erosion indicator in the period 2010-2016.

Among the 281 regions studied, the soil erosion indicator (mean soil loss rates as $\mathrm{tha}^{-1} \mathrm{yr}^{-1}$ ) shows a mean decrease of $-0.8 \%$. For the majority of the regions (73 out of 281 ), the mean soil loss rates for the period 2010-2016 show an insignificant change of -1 to 1\% (yellow color in Figure 5). In practice, there is no significant change of applied soil conservation practices in those regions, mainly located in Central Europe. For 42 regions the decrease of soil loss rates was between 1-3\%, while 37 
regions have a significant decrease in the range 3-5\%. Finally, 38 regions have increased management practices to reduce soil loss rates by more than 5\% in the period 2010-2016. This decrease is mainly observed in Western Europe (Denmark, France, and Germany) as well as in Portugal.

In contrast, a slight increase of 1-3\% of soil loss rates was modelled in 56 regions; these are located in Spain, Poland and part of Italy (Figure 5). Finally, an increase of soil loss rates by more than 3\% is noted in 25 regions, mainly located in South Europe (Greece, Italy and Bulgaria). This mostly has to do with the decrease of conservation tillage in those regions.

\subsection{Model Comparison with Modelled Regional Assessments}

Since 2015, the soil loss estimates by water erosion and the input layers are available in the European Soil Data Centre (ESDAC). This allows public users and researchers to download the data, replicate the methodology and compare their results with the European dataset which is often used as a baseline.

In order to evaluate the performance of the RUSLE2015 at continental scale $\left(>4.5\right.$ million $\left.\mathrm{Km}^{2}\right)$, we decided to do an inter-comparison with independent RUSLE-based assessments at national, regional and local scales. In general, local/regional modelling studies use more accurate (and detailed) input datasets (higher spatial resolution, geo-referenced crops, etc.), and we expect that local/regional experts know their study area better compared to the authors. We have collected nine national datasets (Belgium, Bulgaria, Germany, Denmark, Netherlands, Poland, and Slovakia, 10 regions in Italy and agricultural soils in Austria) from the European Environment Information and Observation Network (EIONET) [48]. In addition, we collected 20 studies which compare their modelling outputs with our RUSLE2015. In total, the $29 \mathrm{local} /$ regional studies are presented in the Appendix A (Table A1; Figure A1). The RUSLE2015 outputs fell in the estimates range of local and regional modelled studies (Figure 6).

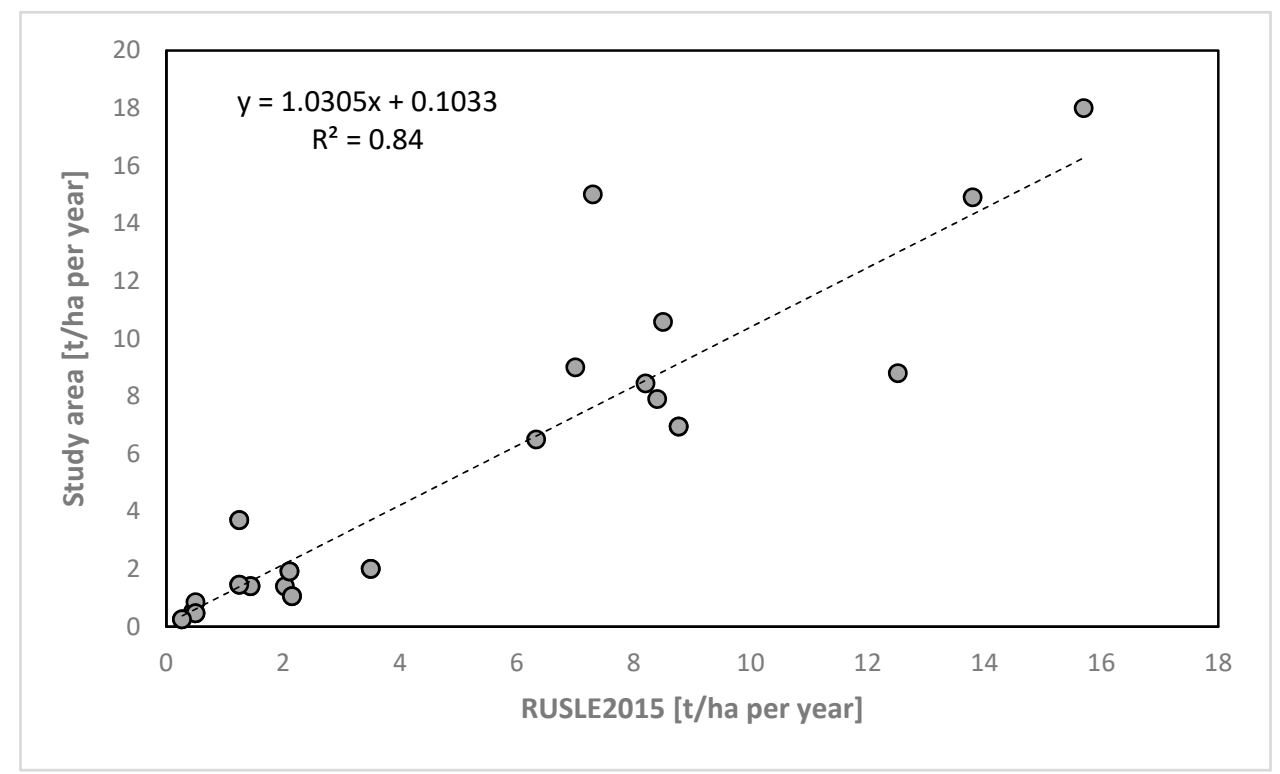

Figure 6. Comparison of the average soil loss estimated by the continental scale model (RUSLE2015) against local/regional estimates obtained from literature.

\subsection{Uncertainties and Model Development}

The RUSLE model does not mechanistically represent the temporal climate variability and, more specific, the changes in rainfall intensity, which is calculated as a mean of measured data ( $\mathrm{R}$ factor) for multiple years. Indeed, a more dynamic (annual) assessment of rain erosivity would be necessary. The northern parts of Europe are experiencing frequent rain events, while the Mediterranean part rarer but more extreme intense rainfall due to climate change (mean increase of rain erosivity by $18 \%$ in the 
EU from 2010 to 2050) [49]. For a more dynamic approach, phenological changes and the inter-annual vegetation protection are necessary to capture the seasonal and inter-annual erosion variability.

Another important uncertainty is the lack of georeferenced data for crops and management practices. The ideal model for estimating soil loss from arable lands should also incorporate the annual crops and the applied soil conservation practices in the field. However, those data are not yet available at the continental scale (ca. 170 million ha); therefore we used statistical data on crop types provided by countries at regional level. Finally, the extremely erosion-sensitive areas (e.g., sparsely vegetated areas according to CORINE) have a very high variable cover spanning from Mediterranean badlands to steep rock slopes in highlands.

We also performed an uncertainty analysis due to possible misclassification of the land cover type as the C-factor shows the highest variability and is the most sensitive input factor [50]. The analysis is based on the assumption that land cover misclassification is more likely to occur in highly fragmented pixels compared to more homogenous areas [51]. The uncertainty can be estimated with the variability of neighboring pixels. After calculating the variance of a pixel neighborhood (Figure A2, Appendix A), it is possible to simulate the probability that a given pixel belongs to a different land cover and the possible impact on the model estimates. For the C-factor, the effect of uncertainty results in an estimate of \pm 488 million tons (MT) (at 0.95 confidence interval) at EU level in 2016. However, two European validation studies have shown that the achieved accuracy both in CORINE Land Cover (CLC) and the CORINE land cover changes layers are above the 85\% [52]. Taking into account the $15 \%$ uncertainty in CORINE layers, we estimated the uncertainty due to land cover misclassification at $\pm 73.2 \mathrm{MT}( \pm 7.6 \%)$ of the 2016 estimates.

To overcome those uncertainties, a more dynamic modelling framework should be developed at continental scale. The dynamic soil erosion approach will incorporate improved estimates of vegetation changes at a high temporal resolution using remote sensing products in combination with detailed databases on crop types, soil characteristics and soil loss information collected at the field parcel and catchment scale in Europe. In addition, the availability of global atmospheric data re-analysis and development of numerical models to estimate rain erosivity regularly are promising for annual soil erosion estimations at continental scale.

\subsection{Scenario Analysis Based on Policy Developments}

RUSLE2015 model is adapted to run policies scenarios. In the impact assessment for the future Common Agricultural Policy (CAP 2021-2027), scenarios with different application rates of cover crops have been used (European Commission, 2018) [14]. The flat rates scenarios showed that cover crops can reduce soil loss in arable lands by $3.9 \%-14 \%$, depending on the application rate of cover crops ranging between $25 \%-75 \%$ of the total arable land. A more targeted scenario envisages the cover crops application in the $75 \%$ of arable lands with soil erosion exceeding $5 \mathrm{tha}^{-1} \mathrm{yr}^{-1}, 50 \%$ cover crops application where soil erosion exceeds $2 \mathrm{t} \mathrm{ha}^{-1} \mathrm{yr}^{-1}$ and $25 \%$ cover crops application where soil erosion exceeds $1 \mathrm{tha}^{-1} \mathrm{yr}^{-1}$. This targeted scenario (variation of cover crops application based on erosion rates) will result in soil erosion rates reduction by $9.5 \%$ in the EU arable lands.

\subsection{Remote Sensing to Model Soil Erosion by Water at Pan-European Scale}

Anthropogenic influences through land use and agriculture substantially accelerate the magnitude of soil erosion processes [53]. Recent advancements in remote sensing, the greater availability of earth observations data and the development of geospatial technologies for data processing have been remarkably improving the capacity of models to represent land cover changes and management practices and their potential effects in terms of soil erosion [54]. Remote sensing is playing an increasingly crucial role in the development of a new generation of soil erosion models. However, the level of integration of remote sensing data and analytical techniques in soil erosion modelling is still heavily influenced by the spatial scale of the modelling application. Small- to local-scale soil erosion modelling applications are moving towards dynamic approaches, which use vegetation indices and 
phenology obtained from remote sensing based canopies to describe the intra-annual variability of crops and natural vegetation in field parcels [55] or representative hillslopes [56]. Recent large-scale modelling approaches like RUSLE2015 show substantial progress in the spatial description of land conditions using remote sensing [57]. However, the increase in the study area generally leads to limitations related to the lower availability of input data and computation capacity. Today's challenge in large-scale soil erosion modelling is to integrate more remote sensing to define the spatiotemporal occurrence of tillage, tillage intensity [58] and other scarcely vegetated surfaces (e.g., wildfires and forest harvesting) [59], which are more exposed to the effect of rainfall and overland flow [60]. Meanwhile, RUSLE2015 uses pan-European remote sensing derived products such as the CORINE land cover (CLC) and the Copernicus fraction of vegetation cover (FCover) to provide first harmonized estimates at pan-European scale which can help decision-makers in both ex-ante and ex-post policy evaluation.

\subsection{Data Availability}

The data of the 2016 soil erosion indicator will be available at the European Soil Data Centre (ESDAC) both as raster files and as aggregated indicators at different regional levels (National; NUTS2: Regions; NUTS3: Provinces). In addition, the updated C-factor and P-factor data will also be provided. Besides the soil erosion data layer and the input factors, we made a number of derived pan-European datasets available such as the stoniness layer, the Rainfall Erosivity Database at European Scale (REDES), the vegetation density, the stone walls density and the grass margins distribution.

\section{Conclusions and Outlook}

The results from this study indicate a slight decrease, both in the mean continental soil loss rate (and, as a consequence in the total soil loss), and in the area affected by severe erosion. This decrease is due to the small increase of applied soil conservation practices in most countries and some small land cover changes (increase of urban areas, a minor decrease of shrublands and conversion of arable lands to pastures). The small mean increase in soil conservation practices at European scale (implying a decrease in the $\mathrm{C}$ - and P-factors) has been offset by a decrease of such conservation practices (and, as a consequence, increase of $\mathrm{C}$ - and $\mathrm{P}$-factors) in more erosion-sensitive areas such as the Mediterranean basin. The small increase of grass margins $(+8.2 \%)$ that was observed between the two LUCAS surveys (2012 and 2015) is expected to further increase due to the greening of the CAP 2014-2020. However, this assumption should be verified with the survey after 2020 .

Soil formation rates found in the literature vary quite significantly as early studies report rates of $0.05-0.5 \mathrm{~mm}$ per year $\left(\approx 1 \mathrm{t} \mathrm{ha}^{-1} \mathrm{yr}^{-1}\right)$ [61] or 1.4-2 $\mathrm{t} \mathrm{ha}^{-1} \mathrm{yr}^{-1}$ [62], while recent ones suggest that soil production can be 3.2-4.5 $\mathrm{t} \mathrm{ha}^{-1} \mathrm{yr}^{-1}$ [63]. Around $25 \%\left(948 \times 10^{3} \mathrm{Km}^{2}\right)$ of the potentially erosion-sensitive study area has soil loss rates above $2 \mathrm{t} \mathrm{ha}^{-1} \mathrm{yr}^{-1}$ (Table 3). Comparing the soil loss rates, which only partially represent all soil erosion processes (gullying, wind erosion, harvest erosion and piping are not included in this study) [53], we conclude that the total soil loss rates are much larger than soil formation rates in large parts of the EU and mitigation measures are therefore very urgent.

Table 3. Percentage (\%) in different soil loss classes for 2010 and 2016.

\begin{tabular}{cccccc}
\hline Year & $<\mathbf{2 ~ t / h a}$ & $\mathbf{> 2} \mathbf{t} / \mathbf{h a}$ & $\mathbf{2 - 5} \mathbf{t} / \mathbf{h a}$ & $\mathbf{5 - 1 0} \mathbf{t} / \mathbf{h a}$ & $\mathbf{> 1 0}$ t/ha \\
\hline 2010 & $75.6 \%$ & $24.4 \%$ & $12.8 \%$ & $6.3 \%$ & $5.3 \%$ \\
\hline 2016 & $75.8 \%$ & $24.2 \%$ & $12.8 \%$ & $6.2 \%$ & $5.2 \%$ \\
Difference & $(+0.2 \%)$ & $(+0.2 \%)$ & $(0 \%)$ & $(-0.1 \%)$ & $(-0.1 \%)$ \\
\hline
\end{tabular}

The marginal decrease of soil erosion in the EU in the period 2010-2016 compared to the $9 \%$ decrease between 2000-2010 needs further investigation to disentangle the drivers behind this trend. In addition to the almost double studied period (10 years vs 6 years) and the land-use change dynamics, we identified additional reasons. The first one is the gradual shift of the agricultural production model from a highly productive one (in the 1990s) with zero conservation practices, to an environmental 
friendly and sustainable agricultural model at the beginning of the century. Then, as we described in the introduction, there is a reinforcement of sustainability policies relevant to soil protection both at the national scale and in the EU. The third reason is the local adjustments driven by farming attitude, awareness raising, national/regional policies, and markets. Finally, we also consider that farmers' incentives should be further linked to their environmental performance (conditionality) guided by a shift of the post-2020 CAP from compliance towards performance and results. An adequate EU legislation for soil protection is currently missing as the proposed Soil Framework Directive was not voted due to a blocking minority of 5 countries causing the consequent withdrawal in 2014. However, the future Common Agricultural Policy (CAP) 2021-2027 can be a framework for better monitoring soil erosion in the EU and for applying soil conservation practices to reduce soil erosion.

The strong bond between remote sensing and inventory statistics formed the basis for pan-European consistent characterizations of soil erosion with local importance and utility. The modelling approach uses harmonized input datasets and highlights the relative differences among regions and countries beyond national borders and local adapted models. RUSLE2015 includes scenario analysis and uncertainties, has performed in different time-steps (2000, 2010, 2016) and allows for hotspot identification. We do recognize that RUSLE2015, like any other soil erosion prediction approach, is not able to $100 \%$ reproduce reality, but we argue that the presented RUSLE-based pan-European approach provides a suitable basis for policy support as it offers process understanding, relative spatial and temporal variations, hotspots identification, scenario development and controlling factors to mitigate soil erosion impact. As such, this modelling approach has been used for both ex-post policy assessment (CAP 2014-2020) and ex-ante policy design (post 2020 CAP). In addition, the results of this pan-European assessment can also provide the basis for a well-planned approach to evaluate regional/national strategic plans against soil erosion and to direct new local monitoring/modelling efforts.

The proposed dataset and the derived indicators (in combination with local/regional studies) can be used in the context of the future CAP as baselines to identify areas vulnerable to soil erosion and to develop better targeted management plans to reduce soil loss rates. The current agri-environmental policies in place need to focus on hotspots and reduce soil erosion rates in agricultural lands where current rates exceed sustainable ones. In addition, more than $6 \%$ of agricultural areas suffer from severe erosion (i.e., soil loss rates $>11 \mathrm{t} \mathrm{ha}^{-1} \mathrm{yr}^{-1}$ ). An important step for environmental protection would be to set a sustainable soil loss target to reduce severe and extreme erosion on agricultural land by 2030. Taking into account the expected future increase of rainfall intensity (and thus rain erosivity) due to climate change, business as usual is not an option and additional policy actions are necessary to ensure environmental sustainability.

Author Contributions: Conceptualization, P.P., J.P., L.M., E.L., S.S., C.B. and P.B.; methodology, P.P., P.B.; software, C.B., S.S.; formal analysis, P.B., P.P., C.B.; investigation, C.B.; resources, C.B., P.P.; data curation, S.S.; writing_original draft preparation, P.P.; writing—review and editing, P.P., P.B., E.L., C.B., J.P.; visualization, P.B.; supervision, P.P.; project administration, L.M., P.P.; funding acquisition, P.P. All authors have read and agreed to the published version of the manuscript.

Funding: This research received no external funding.

Acknowledgments: The authors are thankful to EUROSTAT for providing the data from Farm Structure Survey (FSS) 2016 and to all contributors of LUCAS 2015.

Conflicts of Interest: The authors declare no conflict of interest. 


\section{Appendix A}

Table A1. Comparison of erosion rates between RUSLE2015 model outputs and regional studies.

\begin{tabular}{|c|c|c|c|c|}
\hline Study Area & $\mathrm{Km}^{2}$ & $\begin{array}{l}\text { Mean Soil Loss } \\
\text { Rate RUSLE2015 } \\
\left.\text { (t ha-1 } \text { yr }^{-1}\right)\end{array}$ & $\begin{array}{c}\text { Mean Soil LossRate } \\
\text { from } \\
\text { Study Area } \\
\left(\mathrm{t} \mathrm{ha}^{-1} \mathrm{yr}^{-1}\right)\end{array}$ & Reference \\
\hline Denmark & & 0.5 & 0.85 & [64] \\
\hline Italy & & 8.4 & 7.9 & [65] \\
\hline Finland + plots & & 0.46 & 0.53 & {$[66,67]$} \\
\hline Suchy Creek (CZ) & 3.21 & 13.8 & 14.9 & [68] \\
\hline Svacenicky Creek (SK) & 6.23 & 8.5 & 10.58 & [68] \\
\hline Campia Transilvania (RO) & 3599.34 & 15.7 & 18 & [69] \\
\hline Carapelle (IT) & 493.52 & 12.52 & 8.8 & [70] \\
\hline Kopaninski (CZ) & 7.1 & 6.33 & 6.5 & [71] \\
\hline Plasencia Reservoir (ES) & 359.68 & 2.03 & 1.4 & [72] \\
\hline Gaiana (IT) & 10.87 & 8.2 & 8.44 & [73] \\
\hline Samothraki (GR) & 137.82 & 7.3 & 15 & [74] \\
\hline Sierra de Segura (ES) & 2556.42 & 7 & 9 & [75] \\
\hline Guadalentin (ES) & 2597.28 & 3.5 & 2.01 & [75] \\
\hline Sudetes Mt. catchment (PL) & 1595.66 & 1.25 & 3.7 & [76] \\
\hline Barragem (Alqueva) (PT) & 117.6 & 2.11 & 1.92 & [77] \\
\hline Matera (IT) & 3346.21 & 1.44 & 1.41 & [78] \\
\hline Chianti (IT) & 872.04 & 0.5 & 0.47 & [79] \\
\hline Portofino (IT) & 2.33 & 8.77 & 6.95 & [80] \\
\hline Mati basin (GR) & 104.43 & 0.27 & 0.26 & [81] \\
\hline Aosta (vineyard) (IT) & 0.02 & 1.25 & 1.46 & [82] \\
\hline Austria (agricultural) & & 3.5 & 2.01 & \multirow{9}{*}{ [48] } \\
\hline Belgium & & 1.25 & 3.7 & \\
\hline Bulgaria & & 2.11 & 1.92 & \\
\hline Germany & & 1.44 & 1.41 & \\
\hline Denmark & & 0.5 & 0.47 & \\
\hline Italy & & 8.77 & 6.95 & \\
\hline Netherlands & & 0.27 & 0.26 & \\
\hline Poland & & 1.25 & 1.46 & \\
\hline Slovakia & & 2.15 & 1.06 & \\
\hline
\end{tabular}




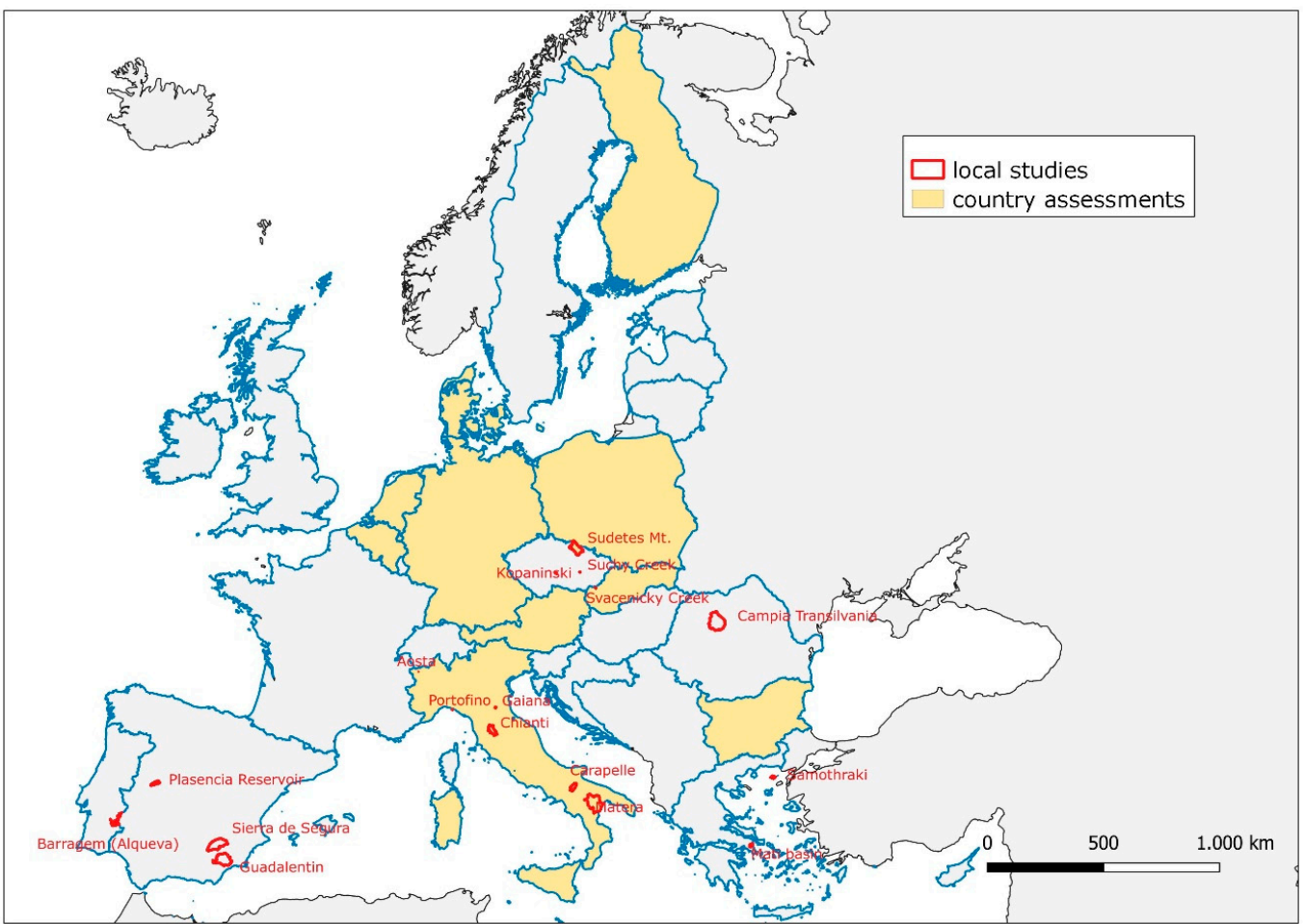

Figure A1. Country assessments (yellow background) and local studies (red line) compared with RUSLE2015 results.

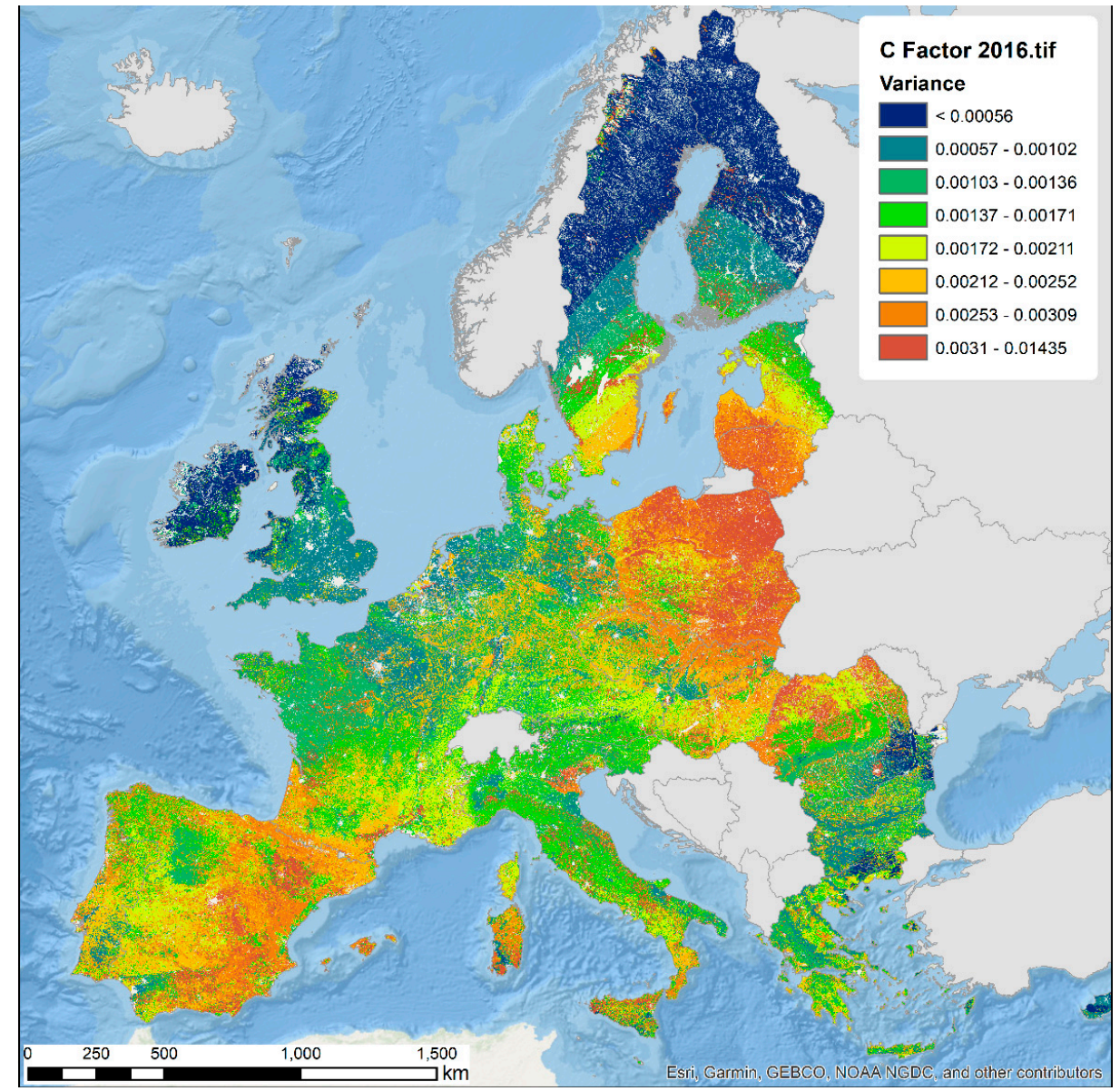

Figure A2. The variance of the C-factor used for estimating the uncertainty. 


\section{References}

1. Glæsner, N.; Helming, K.; de Vries, W. Do current European policies prevent soil threats and support soil functions? Sustainability 2014, 6, 9538-9563. [CrossRef]

2. Juerges, N.; Hansjürgens, B. Soil governance in the transition towards a sustainable bioeconomy-A review. J. Clean. Prod. 2018, 170, 1628-1639. [CrossRef]

3. Cowie, A.L.; Orr, B.J.; Castillo Sanchez, V.M.; Chasek, P.; Crossman, N.D.; Erlewein, A.; Louwagie, G.; Maron, M.; Metternicht, G.I.; Minelli, S.; et al. Land in balance: The scientific conceptual framework for Land Degradation Neutrality. Environ. Sci. Policy 2018, 79, 25-35. [CrossRef]

4. Montanarella, L. Agricultural policy: Govern our soils. Nature 2015, 528, 32-33. [CrossRef] [PubMed]

5. European Environment Agency. European Commission-Soil Thematic Strategy (COM 2006.231); European Environment Agency: Copenhagen, Denmark, 2006.

6. Ronchi, S.; Salata, S.; Arcidiacono, A.; Piroli, E.; Montanarella, L. Policy instruments for soil protection among the EU member states: A comparative analysis. Land Use Policy 2019, 82, 763-780. [CrossRef]

7. Swinbank, A.; Daugbjerg, C. The 2003 CAP Reform: Accommodating WTO Pressures. Comp. Eur. Polit. 2006, 4, 47-64. [CrossRef]

8. Louwagie, G.; Gay, S.H.; Sammeth, F.; Ratinger, T. The potential of European Union policies to address soil degradation in agriculture. L. Degrad. Dev. 2011, 22, 5-17. [CrossRef]

9. Recanati, F.; Maughan, C.; Pedrotti, M.; Dembska, K.; Antonelli, M. Assessing the role of CAP for more sustainable and healthier food systems in Europe: A literature review. Sci. Total Environ. 2019, 653, 908-919. [CrossRef]

10. Matthews, A. Greening agricultural payments in the EU's common agricultural policy. Bio-Based Appl. Econ. 2013, 2, 1-27.

11. Costanza, R.; Fioramonti, L.; Kubiszewski, I. The UN Sustainable Development Goals and the dynamics of well-being. Front. Ecol. Environ. 2016, 14, 59. [CrossRef]

12. Eurostat. Sustainable Development in the European Union-Monitoring Report on Progress towards the SDGs in an EU Context; Eurostat: Brussels, Belgium, 2019.

13. Panagos, P.; Katsoyiannis, A. Soil erosion modelling: The new challenges as the result of policy developments in Europe. Environ. Res. 2019, 172, 470-474. [CrossRef] [PubMed]

14. European Commission. CAP 2021-2027, COMMISSION STAFF WORKING DOCUMENT IMPACT ASSESSMENT SWD (2018) 301 Edition; European Commission: Brussels, Belgium, 2018.

15. European Commission. CAP 2021-27, 2018. EGULATION OF THE EUROPEAN PARLIAMENT AND OF THE COUNCIL-CAP Strategic Plans-COM(2018) 392 Final; European Commission: Brussels, Belgium, 2018.

16. Paleari, S. Is the European Union protecting soil? A critical analysis of Community environmental policy and law. Land Use Policy 2017, 64, 163-173. [CrossRef]

17. Turpin, N.; ten Berge, H.; Grignani, C.; Guzmán, G.; Vanderlinden, K.; Steinmann, H.H.; Siebielec, G.; Spiegel, H.; Perret, E.; Ruysschaert, G.; et al. An assessment of policies affecting Sustainable Soil Management in Europe and selected member states. Land Use Policy 2017, 66, 241-249. [CrossRef]

18. Virto, I.; Imaz, M.J.; Fernández-Ugalde, O.; Gartzia-Bengoetxea, N.; Enrique, A.; Bescansa, P. Soil degradation and soil quality in Western Europe: Current situation and future perspectives. Sustainability 2015, 7, 313-365. [CrossRef]

19. Kirkby, M.J.; Irvine, B.J.; Jones, R.J.A.; Govers, G.; Boer, M.; Cerdan, O.; Daroussin, J.; Gobin, A.; Grimm, M.; Le Bissonnais, Y.; et al. The PESERA coarse scale erosion model for Europe. I.-Model rationale and implementation. Eur. J. Soil Sci. 2008, 59, 1293-1306. [CrossRef]

20. Cerdan, O.; Govers, G.; Le Bissonnais, Y.; Van Oost, K.; Poesen, J.; Saby, N.; Gobin, A.; Vacca, A.; Quinton, J.; Auerswald, K.; et al. Rates and spatial variations of soil erosion in Europe: A study based on erosion plot data. Geomorphology 2010, 122, 167-177. [CrossRef]

21. Panagos, P.; Borrelli, P.; Poesen, J.; Ballabio, C.; Lugato, E.; Meusburger, K.; Montanarella, L.; Alewell, C. The new assessment of soil loss by water erosion in Europe. Environ. Sci. Policy 2015, 54, 438-447. [CrossRef]

22. Renard, K.; Foster, G.; Weesies, G.; McCool, D.; Yoder, D. Predicting soil erosion by water: A guide to conservation planning with the Revised Universal Soil Loss Equation (RUSLE); United States Government Printing: Washington, DC, USA, 1997; p. 404. 
23. Benavidez, R.; Jackson, B.; Maxwell, D.; Norton, K. A review of the (Revised) Universal Soil Loss Equation ((R)USLE): With a view to increasing its global applicability and improving soil loss estimates. Hydrol. Earth Syst. Sci. 2018, 22, 6059-6086. [CrossRef]

24. Alewell, C.; Borrelli, P.; Meusburger, K.; Panagos, P. Using the USLE: Chances, challenges and limitations of soil erosion modelling. Int. Soil Water Conserv. Res. 2019, 7, 203-225. [CrossRef]

25. Borrelli, P.; Robinson, D.A.; Fleischer, L.R.; Lugato, E.; Ballabio, C.; Alewell, C.; Meusburger, K.; Modugno, S.; Schütt, B.; Ferro, V.; et al. An assessment of the global impact of 21st century land use change on soil erosion. Nat. Commun. 2017, 8,1-13. [CrossRef]

26. Liu, Y.; Fu, B.; Liu, Y.; Zhao, W.; Wang, S. Vulnerability assessment of the global water erosion tendency: Vegetation greening can partly offset increasing rainfall stress. L. Degrad. Dev. 2019, 30, 1061-1069. [CrossRef]

27. Panagos, P.; Meusburger, K.; Ballabio, C.; Borrelli, P.; Alewell, C. Soil erodibility in Europe: A high-resolution dataset based on LUCAS. Sci. Total Environ. 2014, 479, 189-200. [CrossRef] [PubMed]

28. Panagos, P.; Borrelli, P.; Meusburger, K. A new European slope length and steepness factor (LS-factor) for modeling soil erosion by water. Geosciences 2015, 5, 117-126. [CrossRef]

29. Panagos, P.; Ballabio, C.; Borrelli, P.; Meusburger, K.; Klik, A.; Rousseva, S.; Tadić, M.P.; Michaelides, S.; Hrabalíková, M.; Olsen, P.; et al. Rainfall erosivity in Europe. Sci. Total Environ. 2015, 511, 801-814. [CrossRef]

30. Copernicus Copernicus Land Monitoring Service. Available online: https://land.copernicus.eu/pan-european/ corine-land-cover (accessed on 6 January 2019).

31. Borrelli, P.; Panagos, P. An indicator to reflect the mitigating effect of Common Agricultural Policy on soil erosion. Land Use Policy 2020, 92, 104467. [CrossRef]

32. Panagos, P.; Borrelli, P.; Meusburger, K.; Alewell, C.; Lugato, E.; Montanarella, L. Estimating the soil erosion cover-management factor at the European scale. Land Use Policy 2015, 48, 38-50. [CrossRef]

33. Panagos, P.; Borrelli, P.; Meusburger, K.; van der Zanden, E.H.; Poesen, J.; Alewell, C. Modelling the effect of support practices (P-factor) on the reduction of soil erosion by water at European scale. Environ. Sci. Policy 2015, 51, 23-34. [CrossRef]

34. Blanco-Canqui, H.; Lal, R. Principles of Soil Conservation and Management; Springer: Berlin, Germany, 2010; ISBN 9789048185290.

35. López-Vicente, M.; Navas, A. Predicting soil erosion with RUSLE in mediterranean agricultural systems at catchment scale. Soil Sci. 2009, 174, 272-282. [CrossRef]

36. Gallego, J.; Delincé, J. The European Land Use and Cover Area-Frame Statistical Survey. In Agricultural Survey Methods; John Wiley \& Sons: Hoboken, NJ, USA, 2010; pp. 149-168.

37. Orgiazzi, A.; Ballabio, C.; Panagos, P.; Jones, A.; Fernández-Ugalde, O. LUCAS Soil, the largest expandable soil dataset for Europe: A review. Eur. J. Soil Sci. 2018, 69, 140-153. [CrossRef]

38. Rickson, R.J. Can control of soil erosion mitigate water pollution by sediments? Sci. Total Environ. 2014, 468, 1187-1197. [CrossRef]

39. Maetens, W.; Poesen, J.; Vanmaercke, M. How effective are soil conservation techniques in reducing plot runoff and soil loss in Europe and the Mediterranean? Earth-Sci. Rev. 2012, 115, 21-36. [CrossRef]

40. Vogel, E.; Deumlich, D.; Kaupenjohann, M. Bioenergy maize and soil erosion-Risk assessment and erosion control concepts. Geoderma 2016, 261, 80-92. [CrossRef]

41. Van Der Zanden, E.H.; Verburg, P.H.; Mücher, C.A. Modelling the spatial distribution of linear landscape elements in Europe. Ecol. Indic. 2013, 27, 125-136. [CrossRef]

42. Yli-Viikari, A.; Hietala-Koivu, R.; Huusela-Veistola, E.; Hyvönen, T.; Perälä, P.; Turtola, E. Evaluating agri-environmental indicators (AEIs)-Use and limitations of international indicators at national level. Ecol. Indic. 2007, 7, 150-163. [CrossRef]

43. Gobin, A.; Jones, R.; Kirkby, M.; Campling, P.; Govers, G.; Kosmas, C.; Gentile, A.R. Indicators for pan-European assessment and monitoring of soil erosion by water. Environ. Sci. Policy 2004, 7, 25-38. [CrossRef]

44. Parris, K. Environmental indicators for agriculture: Overview in OECD countries. In Environmental Indicators and Agricultural Policy; CABI: Oxford, UK, 1999; pp. 25-44.

45. Becker, S.O.; Egger, P.H.; von Ehrlich, M. Going NUTS: The effect of EU Structural Funds on regional performance. J. Public Econ. 2010, 94, 578-590. [CrossRef] 
46. Borrelli, P.; Van Oost, K.; Meusburger, K.; Alewell, C.; Lugato, E.; Panagos, P. A step towards a holistic assessment of soil degradation in Europe: Coupling on-site erosion with sediment transfer and carbon fluxes. Environ. Res. 2018, 161, 291-298. [CrossRef]

47. Panagos, P.; Standardi, G.; Borrelli, P.; Lugato, E.; Montanarella, L.; Bosello, F. Cost of agricultural productivity loss due to soil erosion in the European Union: From direct cost evaluation approaches to the use of macroeconomic models. L. Degrad. Dev. 2018, 29, 471-484. [CrossRef]

48. Panagos, P.; Meusburger, K.; Van Liedekerke, M.; Alewell, C.; Hiederer, R.; Montanarella, L. Assessing soil erosion in Europe based on data collected through a European network. Soil Sci. Plant Nutr. 2014, 60, 15-29. [CrossRef]

49. Panagos, P.; Ballabio, C.; Meusburger, K.; Spinoni, J.; Alewell, C.; Borrelli, P. Towards estimates of future rainfall erosivity in Europe based on REDES and WorldClim datasets. J. Hydrol. 2017, 548, 251-262. [CrossRef]

50. Estrada-Carmona, N.; Harper, E.B.; DeClerck, F.; Fremier, A.K. Quantifying model uncertainty to improve watershed-level ecosystem service quantification: A global sensitivity analysis of the RUSLE. Int. J. Biodivers. Sci. Ecosyst. Serv. Manag. 2017, 13, 40-50. [CrossRef]

51. Langford, W.T.; Gergel, S.E.; Dietterich, T.G.; Cohen, W. Map misclassification can cause large errors in landscape pattern indices: Examples from habitat fragmentation. Ecosystems 2006, 9, 474-488. [CrossRef]

52. Buttner, G. CORINE Land Cover and land cover change products. Remote Sens. Digit. Image Process 2014, 18, 55-74.

53. Poesen, J. Soil erosion in the Anthropocene: Research needs. Earth Surf. Process. Landforms 2018, 84, 64-84. [CrossRef]

54. Panagos, P.; Karydas, C.; Borrelli, P.; Ballabio, C.; Meusburger, K. Advances in soil erosion modelling through remote sensing data availability at European scale. In Second International Conference on Remote Sensing and Geoinformation of the Environment (RSCy2014); International Society for Optics and Photonics: Bellingham, DC, USA, 2014; Volume 9229.

55. Borrelli, P.; Meusburger, K.; Ballabio, C.; Panagos, P.; Alewell, C. Object-oriented soil erosion modelling: A possible paradigm shift from potential to actual risk assessments in agricultural environments. L. Degrad. Dev. 2018, 29, 1270-1281. [CrossRef]

56. Gelder, B.; Sklenar, T.; James, D.; Herzmann, D.; Cruse, R.; Gesch, K.; Laflen, J. The Daily Erosion Project-daily estimates of water runoff, soil detachment, and erosion. Earth Surf. Process. Landforms 2018, 43, 1105-1117. [CrossRef]

57. Vrieling, A. Satellite remote sensing for water erosion assessment: A review. Catena 2006, 65, 2-18. [CrossRef]

58. Borrelli, P.; Lugato, E.; Montanarella, L.; Panagos, P. A New Assessment of Soil Loss Due to Wind Erosion in European Agricultural Soils Using a Quantitative Spatially Distributed Modelling Approach. L. Degrad. Dev. 2017, 28, 335-344. [CrossRef]

59. Borrelli, P.; Panagos, P.; Märker, M.; Modugno, S.; Schütt, B. Assessment of the impacts of clear-cutting on soil loss by water erosion in Italian forests: First comprehensive monitoring and modelling approach. Catena 2017, 149, 770-781. [CrossRef]

60. Bagarello, V.; Ferro, V.; Giordano, G.; Mannocchi, F.; Todisco, F.; Vergni, L. Predicting event soil loss from bare plots at two Italian sites. Catena 2013, 109, 96-102. [CrossRef]

61. Wakatsuki, T.; Rasyidin, A. Rates of weathering and soil formation. Geoderma 1992, 52, 251-263. [CrossRef]

62. Verheijen, F.G.A.; Jones, R.J.A.; Rickson, R.J.; Smith, C.J. Tolerable versus actual soil erosion rates in Europe. Earth-Sci. Rev. 2009, 94, 23-38. [CrossRef]

63. Egli, M.; Dahms, D.; Norton, K. Soil formation rates on silicate parent material in alpine environments: Different approaches-different results? Geoderma 2014, 213, 320-333. [CrossRef]

64. Onnen, N.; Heckrath, G.; Stevens, A.; Olsen, P.; Greve, M.B.; Pullens, J.W.M.; Kronvang, B.; Van Oost, K. Distributed water erosion modelling at fine spatial resolution across Denmark. Geomorphology 2019, 342, 150-162. [CrossRef]

65. Borrelli, P.; Paustian, K.; Panagos, P.; Jones, A.; Schütt, B.; Lugato, E. Effect of Good Agricultural and Environmental Conditions on erosion and soil organic carbon balance: A national case study. Land Use policy 2016, 50, 408-421. [CrossRef]

66. Lilja, H.; Hyväluoma, J.; Puustinen, M.; Uusi-Kämppä, J.; Turtola, E. Evaluation of RUSLE2015 erosion model for boreal conditions. Geoderma Reg. 2017, 10, 77-84. [CrossRef] 
67. Puustinen, M.; Turtola, E.; Kukkonen, M.; Koskiaho, J.; Linjama, J.; Niinioja, R.; Tattari, S. VIHMA-A tool for allocation of measures to control erosion and nutrient loading from Finnish agricultural catchments. Agric. Ecosyst. Environ. 2010, 138, 306-317. [CrossRef]

68. Honek, D.; Caletka, M. Longtherm and event-based modelling of soil water erosion in small catchments. Int. Multidiscip. Sci. GeoConference Surv. Geol. Min. Ecol. Manag. SGEM 2019, 13, 339-346.

69. Roşian, G.; Csaba, H.; Kinga-Olga, R.; Boţan, C.N.; Gavrilă, I.G. Assessing landslide vulnerability using bivariate statistical analysis and the frequency ratio model. Case study: Transylvanian Plain (Romania). Zeitschrift Für Geomorphol. 2016, 60, 359-371. [CrossRef]

70. Abdelwahab, O.M.M.; Ricci, G.F.; De Girolamo, A.M.; Gentile, F. Modelling soil erosion in a Mediterranean watershed: Comparison between SWAT and AnnAGNPS models. Environ. Res. 2018, 116, 363-376. [CrossRef]

71. Jakubínský, J.; Pechanec, V.; Procházka, J.; Cudlín, P. Modelling of soil erosion and accumulation in an agricultural landscape-A comparison of selected approaches applied at the small stream basin level in the Czech Republic. Water 2019, 11, 404. [CrossRef]

72. Sánchez, Y.; Martínez-Graña, A.; Santos-Francés, F.; Yenes, M. Influence of the sediment delivery ratio index on the analysis of silting and break risk in the Plasencia reservoir (Central System, Spain). Nat. Hazards 2018, 91, 1407-1421. [CrossRef]

73. Pavanelli, D.; Cavazza, C. River suspended sediment control through riparian vegetation: A method to detect the functionality of riparian vegetation. Clean-Soil. Air Water 2010, 38, 1039-1046. [CrossRef]

74. Panagopoulos, Y.; Dimitriou, E.; Skoulikidis, N. Vulnerability of a northeast Mediterranean island to soil loss. Can grazing management mitigate erosion? Water 2019, 11, 1491. [CrossRef]

75. Eekhout, J.P.; De Vente, J. How soil erosion model conceptualization affects soil loss projections under climate change. Prog. Phys. Geogr. Earth Environ. 2019, 0309133319. [CrossRef]

76. Latocha, A.; Szymanowski, M.; Jeziorska, J.; Stec, M.; Roszczewska, M. Effects of land abandonment and climate change on soil erosion-An example from depopulated agricultural lands in the Sudetes Mts., SW Poland. Catena 2016, 145, 128-141. [CrossRef]

77. Ferreira, V.; Panagopoulos, T. Seasonality of soil erosion under Mediterranean conditions at the Alqueva dam watershed. Environ. Manag. 2014, 54, 67-83. [CrossRef]

78. Mancino, G.; Nolè, A.; Salvati, L.; Ferrara, A. In-between forest expansion and cropland decline: A revised USLE model for soil erosion risk under land-use change in a Mediterranean region. Ecol. Indic. 2016, 71, 544-550. [CrossRef]

79. Napoli, M.; Cecchi, S.; Orlandini, S.; Mugnai, G.; Zanchi, C.A. Simulation of field-measured soil loss in Mediterranean hilly areas (Chianti, Italy) with RUSLE. Catena 2016, 145, 246-256. [CrossRef]

80. Rellini, I.; Scopesi, C.; Olivari, S.; Firpo, M.; Maerker, M. Assessment of soil erosion risk in a typical mediterranean environment using a high resolution RUSLE approach (Portofino promontory, NW-Italy). J. Maps 2019, 15, 356-362. [CrossRef]

81. Efthimiou, N.; Psomiadis, E.; Panagos, P. Fire severity and soil erosion susceptibility mapping using multi-temporal Earth Observation data: The case of Mati fatal wildfire in Eastern Attica, Greece. Catena 2020, 187, 104320. [CrossRef] [PubMed]

82. Biddoccu, M.; Zecca, O.; Audisio, C.; Godone, F.; Barmaz, A.; Cavallo, E. Assessment of Long-Term Soil Erosion in a Mountain Vineyard, Aosta Valley (NW Italy). L. Degrad. Dev. 2018, 29, 617-629. [CrossRef]

(C) 2020 by the authors. Licensee MDPI, Basel, Switzerland. This article is an open access article distributed under the terms and conditions of the Creative Commons Attribution (CC BY) license (http://creativecommons.org/licenses/by/4.0/). 